\title{
ANALISIS PERANCANGAN INVENTARIS BARANG PADA SEKOLAH MENENGAH KEJURUAN PERTANIAN PEMBANGUNAN (SMK-PP) NEGERI KUPANG
}

\author{
Ricky Imanuel Ndaumanu \\ STMIK Widya Dharma Pontianak; Jl. H.O.S. Cokroaminoto no 445, 731966/ 739191 \\ e-mail: ricky_ndaumanu@ymail.com
}

\begin{abstract}
Abstrak
Dewasa ini perkembangan teknologi informasi semakin berkembang, hal ini sejalan dengan perkembangan komputer yang semakin hari semakin berkembang pesat. Teknologi dan informasi merupakan dua hal yang tidak dapat dipisahkan satu sama lain. Perkembangan teknologi komunikasi merupakan alternatif bagi suatu perusahaan untuk menunjang pengolahan informasi yang baik. Apabila pengolahan informasi tidak teratur dan tidak terkoordinasi dengan baik akan mengakibatkan kurangnya pengetahuan informasi secara tepat dan akurat. Manfaat perkembangan teknologi informasi saat ini belum sepenuhnya digunakan oleh setiap perusahaan swasta maupun instansi pemerintah, belum begitu memanfaatkan penggunaan sarana komputer sebagai media pengolah informasi. Pengontrolan terhadap inventaris barang sangat dibutuhkan sehingga barang masih layak pakai dan yang tidak terpakai lagi dapat di control dengan baik. Sistem yang digunakan dalam pendataan barang inventaris masih menggunakan manual (menggunakan buku besar), sehingga mengalami kesulitan dalam memberikan laporan kepada pimpinan tentang barang-barang yang ada pada setiap bagian unit kerja terhadap barang-barang yang terpakai maupun keadaan barang-barang yang masih layak dipakai. Sehingga demikian efisiensi dan efektifitas dalam melakukan pengontrolan terhadap barang-barang pada setiap bagian unit kerja dapat terlaksana dengan baik. oleh karena itu pengontrolan terhadap barangbarang inventaris dibutuhkan adanya suatu aplikasi pencatatan inventaris yang cepat, tepat dan akurat.Untuk memudahkan pelaksanaan pendataan barang-barang yang ada pada setiap unit kerja, maka mengingat program Microsoft Visual Basic 6.0 sebagai salah satu penghasil program termudah dan tercepat, sehingga mamudahkan pemrograman untuk berinteraksi dengan elemen untuk setiap bentuk pemrograman. Dari hasil implementasi sistem, disimpulkan bahwa dengan menggunaka Software ini dapat membantu proses pendataan inventaris barang-barang yang ada pada setiap unit kerja di SMK-PP Negeri Kupang.
\end{abstract}

Kata kunci-Teknologi, implementasi, Software, inventaris

\begin{abstract}
Nowadays, the development of technology information is more famous, this is in line with the development of computer that improved rapidly. Information and technology are two things that can not be separated from one to another. The development of communication technology is an alternative way for a company to support the processing of good information. If the processing of the informations irregular and uncoordinated well, it will causes minimum appropriate and accurate informations. The benefits of the information technology development as the advantages of the use of computer in facilitate the processing of information are not fully used by any private companies and government agencies yet.Inventory Controlling of goods is needed to makethe goods are still on good condition and for the goods that no longer used also can be control well. The system used in the collecting the inventory data items still used manual (using the ledger), thus causes the difficulties in reporting to the leaders about the items that exist in the office even in every unit of the goods that already used and the the goods that havent used yet. So, the efficiency and effectiveness in controlling the goods on each section of the unit can be done well. Therefore, the inventory items controlling is necessary use an application that faster, precise and accurate.To facilitate the implementation of collecting the inventory data items in each unit of
\end{abstract}


work become easier, then it should use a program like Microsoft Visual Basic 6.0. This program is one of the easiest and fastest program in interact with the elements of programming in any form of programming. As the results of the implementation system, it was concluded that the use of this software can help the process of collecting the inventory data items that exist in every work unit in SMK Negeri Kupang-PP.

Keywords - Technology, implementation, software, inventory

\section{PENDAHULUAN}

Kemajuan teknologi informasi yang berkembang dengan sangat cepat berpengaruh pada penggunaan teknologi komputer diberbagai sektor kehidupan. mulai dari penggunaan secara pribadi, lembaga pendidikan, serta instansi pemerintahan, swasta maupun asing.

Sekolah Menengah Kejuruan Pertanian Pembangunan (SMK-PP) Negeri Kupang saat ini merasa perlu meningkatkan kinerjanya dengan memanfaatkan kemajuan teknologi informasi yang berbasis komputer guna mendukung bagian tata usaha dalam membantu proses pendataan Barang Sekolah Menengah Kejuruan Pertanian Pembangunan (SMK-PP) Negeri Kupang. Hal ini dilatarbelakangi dengan proses kegiatan atau tindakan untuk melakukan perhitungan, pengurusan, penyelenggaraan, pengaturan, pencatatan data dan pelaporan barang milik pemerintah dalam unit organisasi yang masih dilakukan secara manual sehingga sering kali menimbulkan kendala dalam hal efisiensi waktu, ketelitian, kearsipan, kecepatan informasi yang dihasilkan untuk memperkuat posisi pengambilan keputusan.

Sampai saat ini belum adanya sistem yang menyajikan informasi mengenai pendataan barang inventaris kantor. Ketidakpastian kedepan apabila semakin banyak orang yang membutuhkan informasi tentang hal diatas maka perlu dipikirkan mengenai sistem yang dapat membantu dalam memperoleh informasi mengenai hal-hal diatas. Hal ini dirasakan sangat perlu oleh penulis karena dengan adanya aplikasi yang memudahkan Sub Bagian Tata Usaha di Sekolah Menengah Kejuruan Pertanian Pembangunan (SMK-PP) Negeri Kupang dalam proses pendataan Barang Inventaris Kantor. Permasalahan yang timbul pada Sekolah Menengah Kejuruan Pertanian Pembangunan (SMK-PP) Negeri Kupang adalah Bagaimana cara merancang Pendataan Barang Inventaris Sekolah Menengah Kejuruan Pertanian Pembangunan (SMK-PP) Negeri Kupang.

Dalam penelitian ini mengacu dari penelitian sebelumnya Elisabeth thedens, 2009, "program bantu pendataan barang inventaris kantor pada dinas tenaga kerja dan transmigrasi Provinsi Nusa Tenggara Timur" [1]. Dalam laporan ini penulis Membuat perangkat lunak Program Bantu Pendataan Barang Inventaris Kantor pada Sub Bagian Tata Usaha Dinas Tenaga Kerja Dan Transmigrasi Provinsi Nusa Tenggara Timur. Kelebihannya adalah penulis sudah menggunakan program bantu dalam pendataan, cepat dalam pelaporannya dan sedangkan yang lama masih secara manual dan kurang akurat. Kelemahan dari program ini adalah dalam pelaporan yang masih sedikit lambat. Didalam Skripsi Indra Haryanto Ali, 2011, Aplikasi rencana kerja tahunan puskesmas pada dinas kesehatan kota kupan berbasis client server [2]. Dalam pengelolaan data atau informasi pada Dinas Kesehatan sudah menggunakan media komputerisasi namun dalam proses pengerjaannya terdapat banyak kendala yang dirasakan, karena tidak adanya sistem database yang khusus dalam penanganan data pada program rencana kerja tahunan puskesmas dan kurang fokusnya rencana kerja pada puskesmas dikarenakan rencana usulan kegiatan (RUK) pada masing-masing puskesmas dikumpulkan kemudian dirandom (acak) sehingga dalam pengerjaan rencana kerja tahunan pada puskesmas tersebut tidak terfokus dengan baik

\section{METODE PENELITIAN}

Metode adalah suatu cara yang digunakan untuk merubah cara kerja sistem lama menjadi sistem baru. Metode yang dipakai dalam membuat Program Pendataan Barang Inventaris Kantor ini terdiri dari beberapa tahapan antara lain : 


\section{Metode Penelitian}

Metodologi penelitian adalah langkah-langkah yang digunakan agar hipotesis penelitian dapat teruji secara empirik (Sugiyono, 2003) [3] . Metode penelitian yang digunakan oleh penulis adalah Model Penelitian Tindakan (Action Research).

Kurt Lewin mengembangkan penelitian tindakan atas dasar konsep pokok bahwa penelitian tindakan terdiri dari empat komponen pokok yang juga menunjukkan langkah, yaitu :

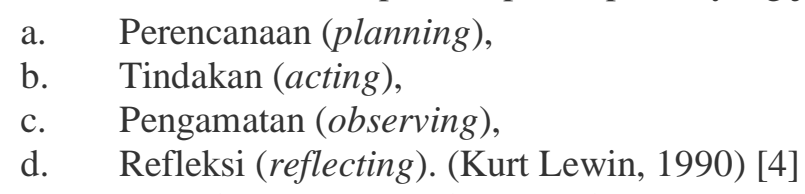

Hubungan antara keempat komponen tersebut menunjukkan sebuah siklus atau kegiatan yang berulang. "Siklus" inilah yang sebetulnya menjadi salah satu ciri utama dari penelitian tindakan, yaitu bahwa penelitian tindakan harus dilaksanakan dalam bentuk siklus, bukan hanya satu kali intervensi saja. (Suharsimi Arikunto, 2006, hlm. 92) [5]

Apabila digambarkan dalam bentuk visualisasi, maka model Kurt Lewin akan tergambar dalam bagan lingkaran seperti berikut ini :

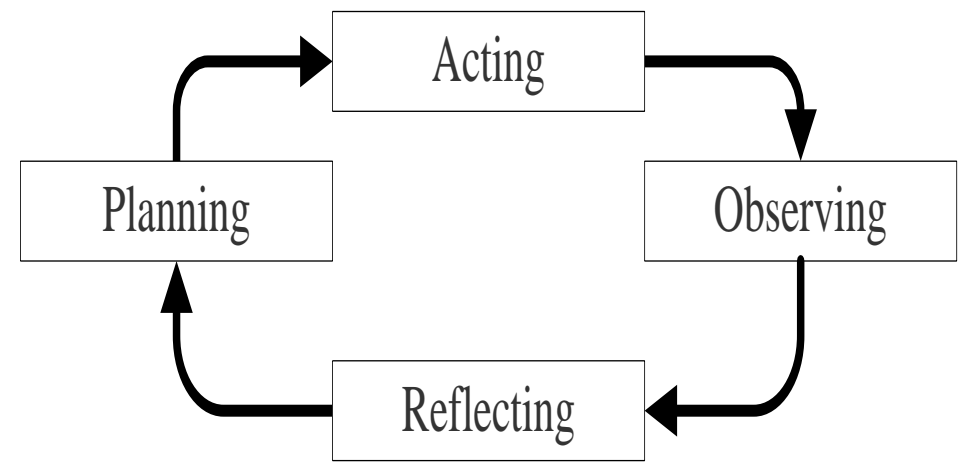

Gambar 1. (Kurt Lewin, 1990) [4]

Mengingat begitu luasnya ruang lingkup yang ada pada Sekolah Menengah Kejuruan Pertanian Pembangunan (SMK-PP) Negeri Kupang, maka penulis mengadakan penelitian hanya pada satu bagian yaitu pada bagian Tata Usaha.

\section{Pengambilan data}

Metode pengumpulan data yang digunakan dalam penelitian adalah observasi, wawancara dan kuesioner. Pengumpulan data dilakukan untuk memperoleh informasi yang dibutuhkan dalam rangka mencapai tujuan penelitian. Metode pengumpulan data dalam penelitian ini adalah sebagai berikut :

a. Observasi

Merupakan metode pengumpulan data dengan cara melakukan pengamatan secara langsung pada obyek yang diteliti yaitu pada tata usaha SMK PP yang meliputi data kualitatif dan data kuantitatif diobservasi. Tujuan observasi adalah mendeskripsikan seting yang dipelajari, aktivitasaktivitas yang berlangsung, orang-orang yang terlibat dalam aktivitas, dan makna kejadian dilihat dari perpektif mereka yang terlihat dalam kejadian yang diamati tersebut. Menurut Nawawi dan Martini (1991) [6] observasi adalah pengamatan dan pencatatan secara sistimatik terhadap unsur-unsur yang tampak di SMK PP.

\section{b. Wawancara}

Wawancara adalah percakapan yang dilakukan oleh kedua orang untuk maksud tertentu yaitu antara peneliti dengan informan (Moleong, 2004: 186) [7]. Informan dalam penelitian ini adalah pegawai tata usaha yang melakukan pendataan inventaris barang pada SMK PP. Pedoman wawancara digunakan untuk mengingatkan interviewer mengenai aspek-aspek apa yang 
harus dibahas, juga menjadi daftar pengecek (check list) apakah aspek-aspek relevan tersebut telah dibahas atau ditanyakan. Dengan pedoman demikian interviwer harus memikirkan bagaimana pertanyaan tersebut akan dijabarkan secara kongkrit dalam kalimat tanya, sekaligus menyesuaikan pertanyaan dengan konteks aktual saat wawancara berlangsung. Bogdan dan Taylor (Moleong, 2007:3) [8] mengemukakan bahwa metodologi kualitatif merupakan prosedur penelitian yang menghasilkan data deskriptif berupa kata-kata tertulis maupun lisan dari orang-orang dan perilaku yang diamati. Menururt Punch (1998: 4) [9] metode penelitian kuantitatif merupakan penelitian empiris dimana data adalah dalam bentuk sesuatu yang dapat dihitung atau angka. Penelitian kuantitatif memerhatikan pada pengumpulan dan analisis data dalam bentuk numeric

\section{c. Dokumen}

Pengambilan data melalui dokumen tertulis maupun elektronik dari lembaga atau institusi sesui dengan yang diangkat dalam skripsi ini yaitu di SMK PP Negeri Kupang. Dokumen diperlukan untuk mendukung kelengkapan data yang lain.

\section{Metode perancangan}

Tahapan-tahapan penyelesaian dimulai dari flowchart atau bagan alur, diagram konteks, diagram berjenjang, DFD (Data Flow Diagram), kamus data arus data, kamus data tabel, ERD (Entity Relation Diagram), Perancangan input dan perancangan output.

a. Alur Dokumen

Didalam alur dokumen ini memuat proses-proses pendataan inventaris di SMK PP :

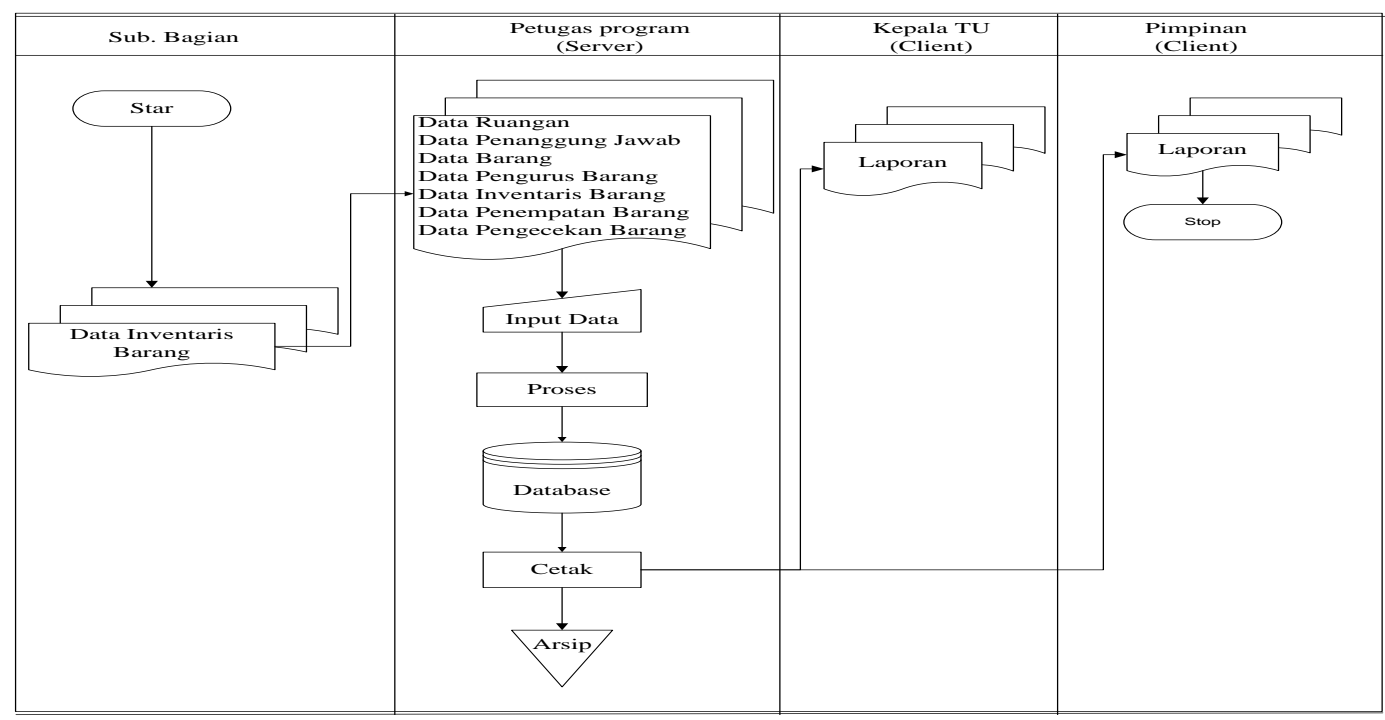

\section{Gambar 2. Alur Dokumen}

b. Diagram Konteks

Semua entitas eksternal yang ditunjukkan pada diagram konteks berikut aliran data-aliran data utama menuju dan dari sistem. 


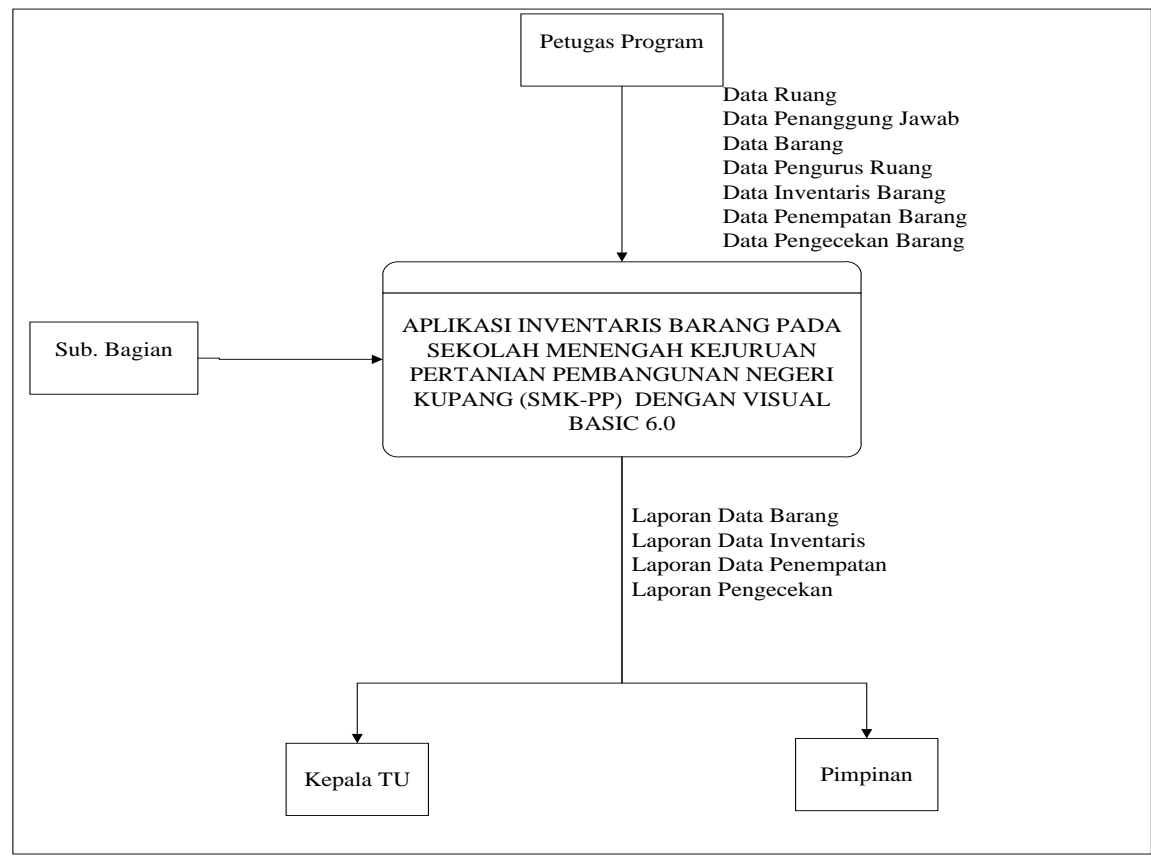

\section{Gambar 3. Diagram Konteks}

\section{c. Diagram Berjenjang}

Menggambarkan struktur dari sistem Berupa suatu bagan berjenjang yang menggambarkan semua proses yang ada disistem. Dipergunakan untuk mempersiapkan penggambaran DFD ke level lebih bawah lagi yang terliha pada gambar 4 :

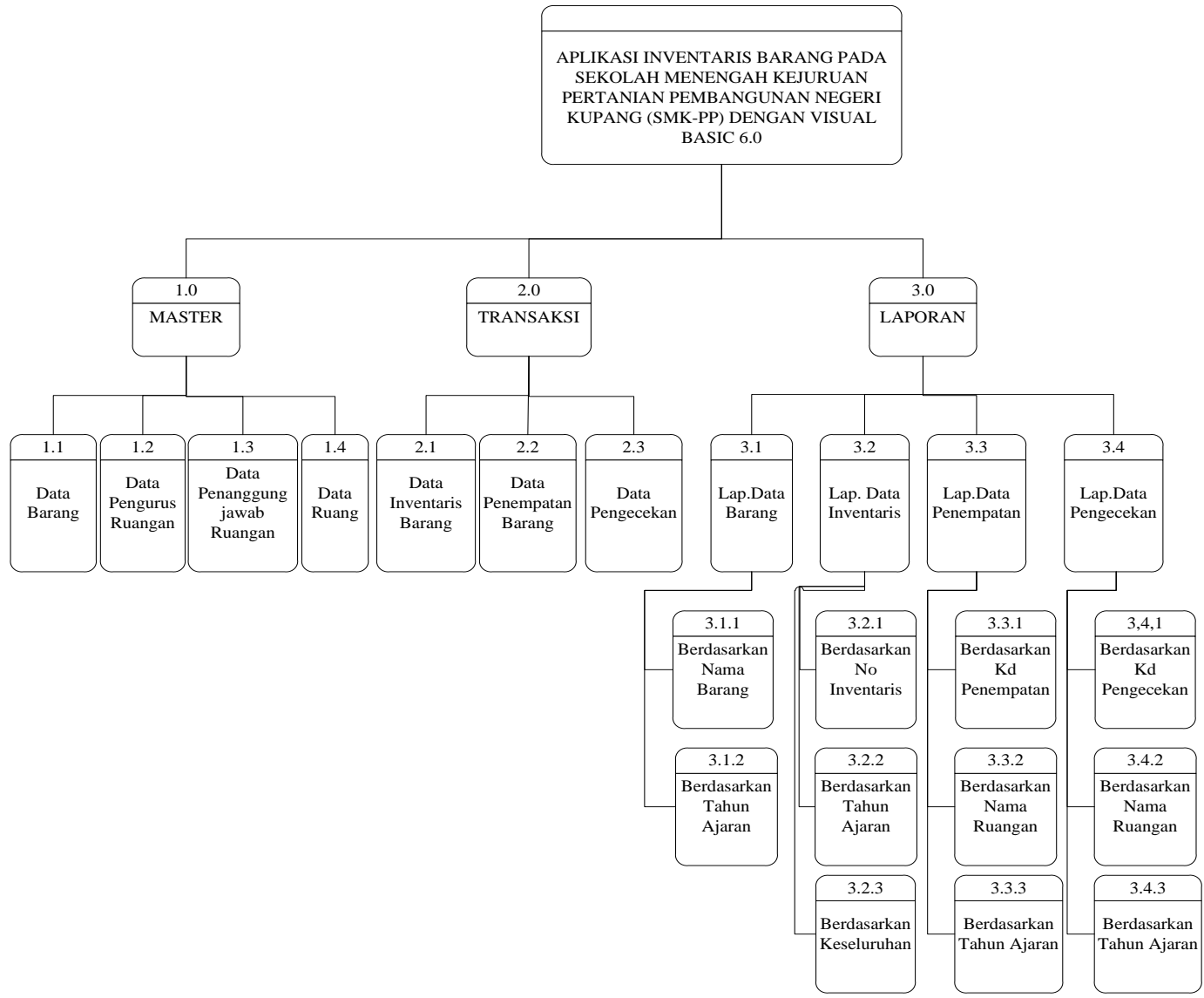

\section{Gambar 4. Digram Berjenjang}


Dari gambar diatas dapat dijelaskan sebagai berikut : dari sistem pelayanan data servis terdapat beberapa proses diantaranya master data, transaksi, dan laporan. Pada proses master data terdapat beberapa proses diantaranya proses data barang, proses data pengurus ruangan, proses data penanggung jawab ruangan, proses data ruangan dan proses data ruangan. Proses transaksi memproses transaksi data inventaris barang, data penempatan barang dan pengecekan. Proses laporan proses laporan adalah laporan pertanggung jawaban yang diserahkan kepada pimpinan.

\section{d. DFD (Data Flow Diagram)}

Data Flow Diagram (DFD) adalah model logika data atau proses yang dibuat untuk menggambarkan dari mana asal data, kemana tujuan data dan dimana data tersebut disimpan. Berikut ini adalah gambar DFD dari aplikasi inventaris barang pada Sekolah Menengah Kejuruan Pertanian Pembangunan Negeri Kupang (Smk-PP) dengan Visual Basic 6.0

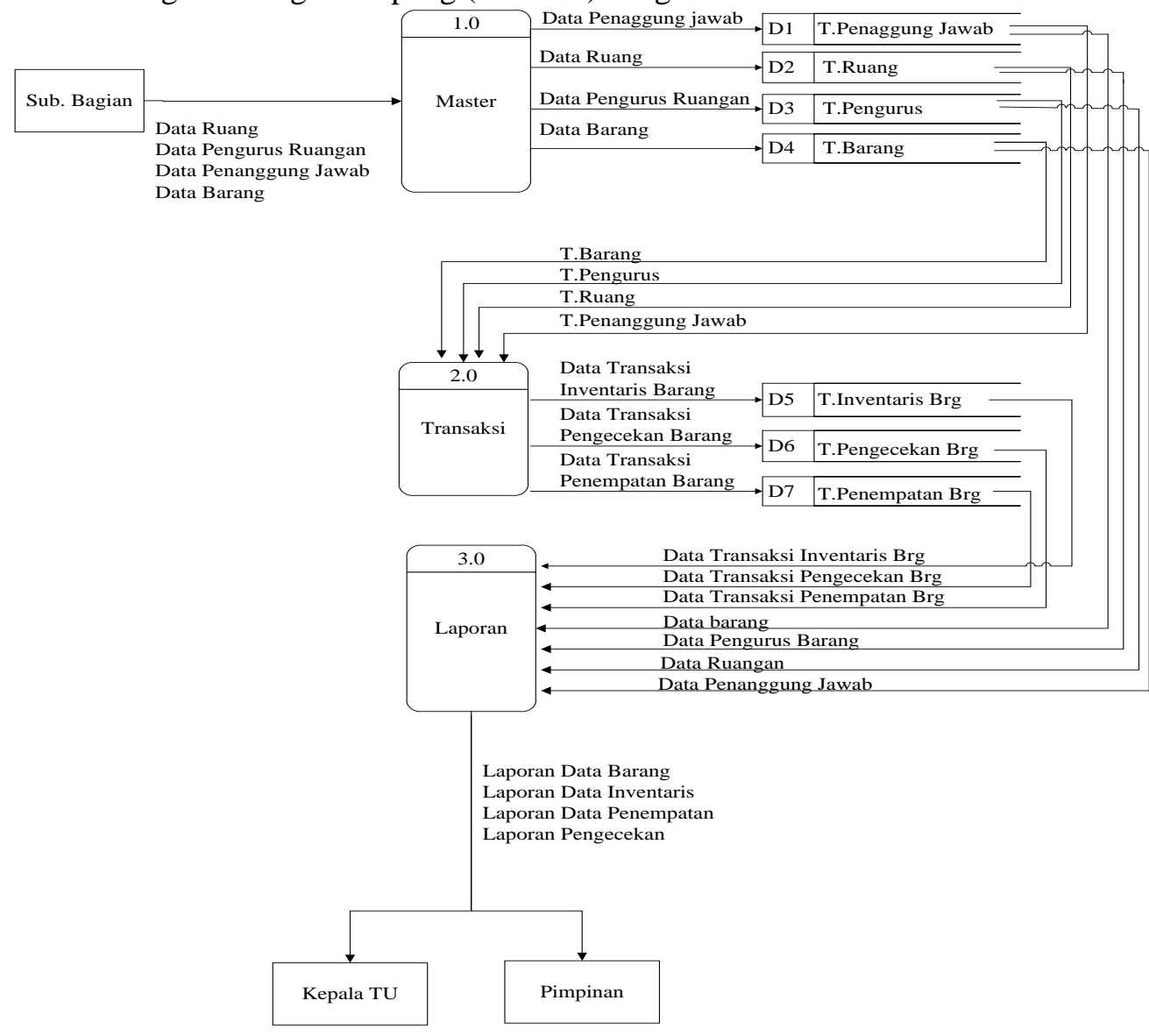

\section{Gambar 5. DFD (Data Flow Diagram)}

Model ini menggambarkan sistem sebagai jaringan kerja antar fungsi yang berhubungan satu sama lain dengan aliran dan penyimpanan data (selanjutnya kita sebut DFD). Sebagai perangkat analisis, model ini hanya mampu memodelkan sistem dari satu sudut pandang yaitu sudut pandang fungsi 
e. $\quad$ ERD (Entiti Relationship Diagram)

Merupakan proses perancangan entity relationship digunakan untuk menunjukan hubungan antara entity yang direlasikan dengan kunci relasi yaitu kunci utama dari masing-masing entity relasi antara satu file dengan file yang saling berhubungan seperti yang terlihat pada gambar 6:

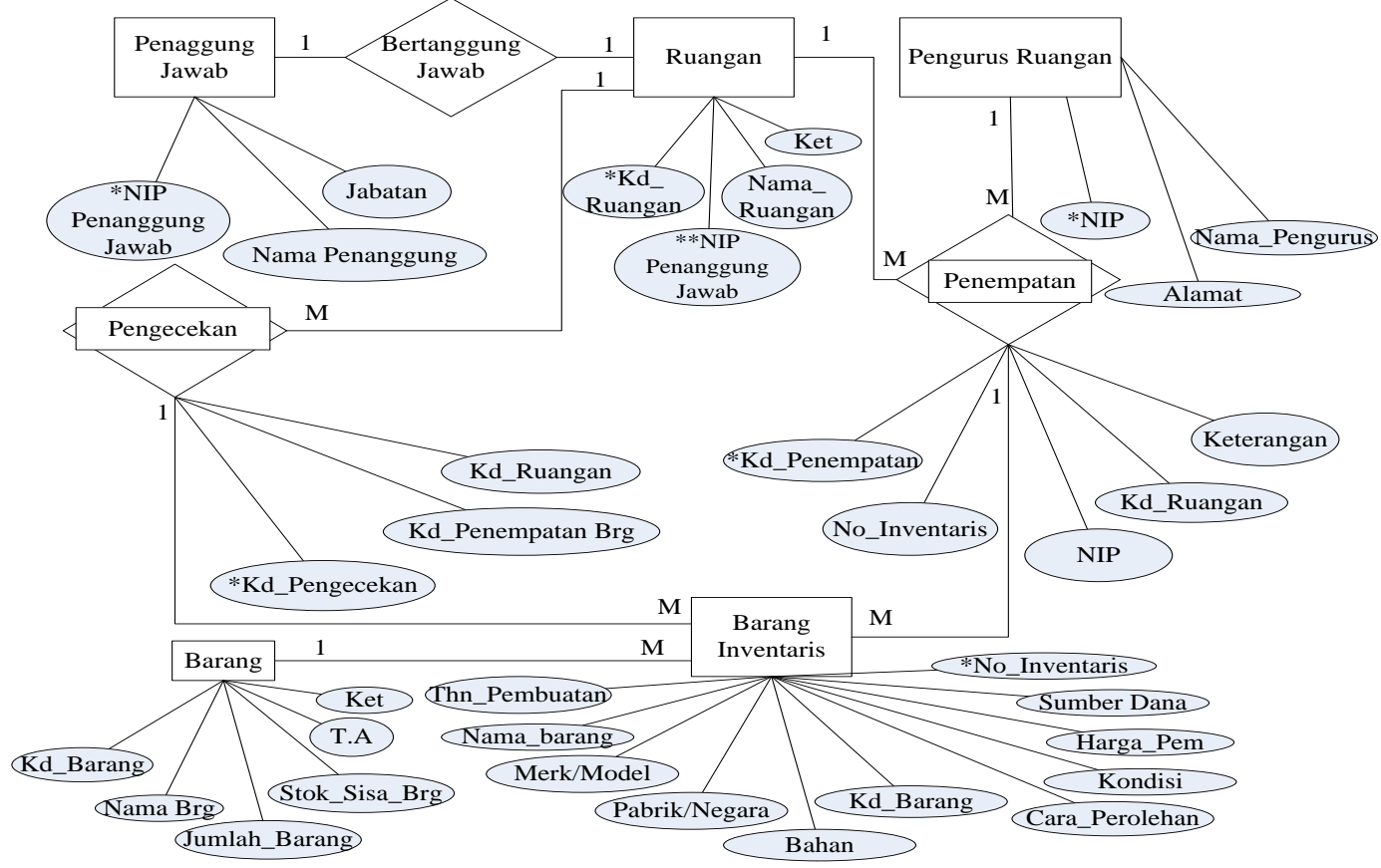

\section{Gambar 6. ERD (Entiti Relationship Diagram)}

\section{HASIL DAN PEMBAHASAN}

Berdasarkan pembahasan tahap perancangan sistem, maka pada hasil dan pembahasan ini akan dijabarkan cara atau implementasi dari aplikasi inventaris barang pada Sekolah Menengah Kejuruan Pertanian Pembangunan Negeri Kupang (SMK-PP) dengan Visual Basic 6.0.

1. Tampilan Menu Utama

Bagian-bagian Menu Utama dibawah ini mempunyai 3 option yaitu : Master, Transaksi, Laporan. Tampilan menu utama dapat dilihat pada gambar 7

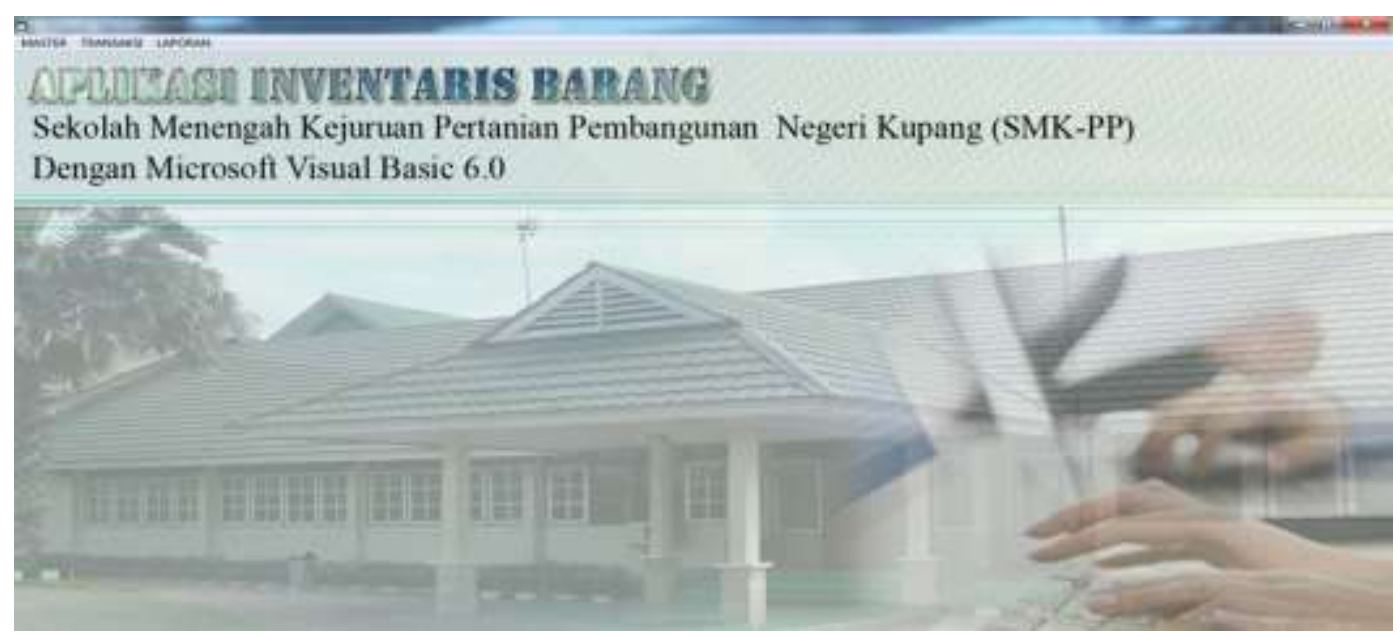

Gambar 7. Tampilan Menu Utama 


\section{Tampilan Sub-Sub Menu}

Adapun tampilan dari sub-sub menu antara lain:Sub Menu Master dalam sub menu master terdapat 5 anak sub menu lagi antara lain dalah menu barang digunakan untuk input data Barang seperti : kode, nama, jumlah, Stok sisa, Tahun ajar dan keterangan barang . Pada form ini juga terdapat tiga tombol 5 yaitu : tombol tambah untuk menambah data, tombol simpan untuk menyimpan data yang sudah di input, tombol edit untuk mengedit data atau mengubah data, tombol hapus untuk menghapus data yang sudah terdapat pada record data barang masuk dan tombol tutup untuk keluar dari form Data barang. Menu data pengurus barang digunakan untuk input data pengurus ruang seperti : NIP, nama dan alamat . Pada form ini juga terdapat tiga tombol 5 yaitu : tombol tambah untuk menambah data, tombol simpan untuk menyimpan data yang sudah di input, tombol edit untuk mengedit data atau mengubah data, tombol hapus untuk menghapus data yang sudah terdapat pada record data Pengurus Ruangan masuk dan tombol tutup untuk keluar dari form Data Pengurus Ruang. Menu data penanggung jawab ruangan digunakan untuk input data Penanggung jawab seperti : NIP, nama dan jabatan penanggung. Pada form ini juga terdapat tiga tombol 5 yaitu : tombol tambah untuk menambah data, tombol simpan untuk menyimpan data yang sudah di input, tombol edit untuk mengedit data atau mengubah data, tombol hapus untuk menghapus data yang sudah terdapat pada record data penanggung jawab dan tombol tutup untuk keluar dari form Data penanggung jawab. Menu data ruangan digunakan untuk input data Penanggung jawab seperti : NIP, nama dan jabatan penanggung. Pada form ini juga terdapat tiga tombol 5 yaitu : tombol tambah untuk menambah data, tombol simpan untuk menyimpan data yang sudah di input, tombol edit untuk mengedit data atau mengubah data, tombol hapus untuk menghapus data yang sudah terdapat pada record data penanggung jawab dan tombol tutup untuk keluar dari form Data penanggung jawab. Menu keluar Pada sub menu ini digunakan pada saat akan keluar dari aplikasi ini

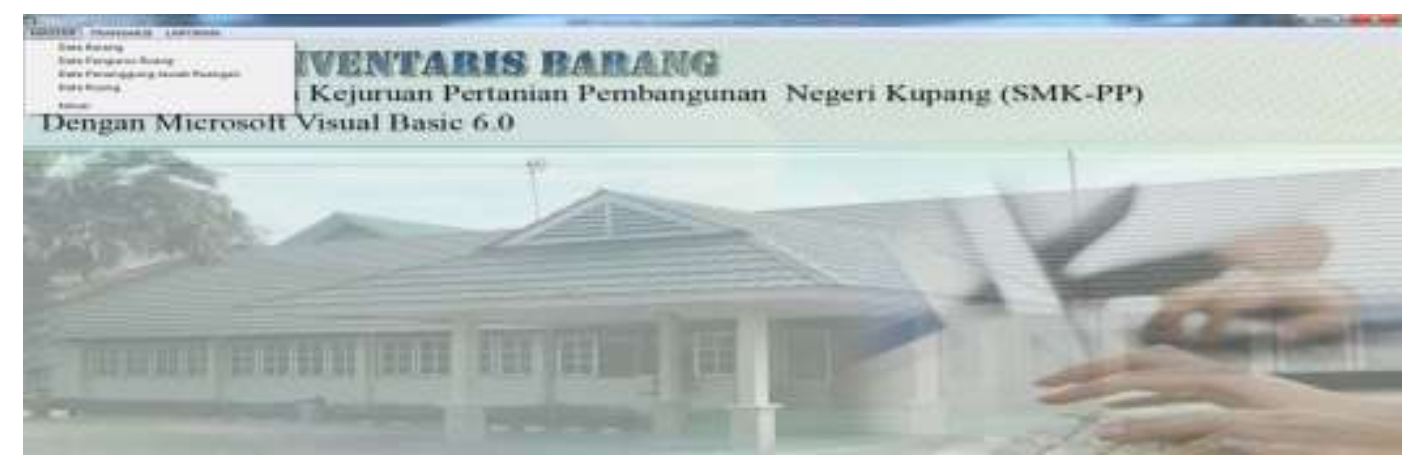

\section{Gambar 8. Sub Menu Master}

\section{a. Sub Menu Transaksi}

Didalam sub input menu transaksi terdapat 3 anak sub menu yang berfungsi untu: menu data inventaris barang digunakan untuk input data Inventaris barang seperti: kode barang, nama barang, model dan lain. Pada form ini juga terdapat tiga tombol 5 yaitu : tombol tambah untuk menambah data, tombol simpan untuk menyimpan data yang sudah di input, tombol edit untuk mengedit data atau mengubah data, tombol hapus untuk menghapus data yang sudah terdapat pada record data inventaris barang dan tombol tutup untuk keluar dari form data inventaris barang. Sub menu data penempatan barang digunakan untuk input data penempatan barang seperti: kode penempatan, kode ruangan, nama penanggung jawab dan lain-lain. Pada form ini juga terdapat tiga tombol 5 yaitu : tombol tambah untuk menambah data, tombol simpan untuk 
menyimpan data yang sudah di input, tombol edit untuk mengedit data atau mengubah data, tombol hapus untuk menghapus data yang sudah terdapat pada record data penempatan barang dan tombol tutup untuk keluar dari form data penempatan barang. Sub menu data pengecekan barang digunakan untuk input data pengecekan barang barang seperti: id_cek, id_tempat, nama barang, dan lain-lain. Pada form ini juga terdapat tiga tombol 5 yaitu : tombol tambah untuk menambah data, tombol simpan untuk menyimpan data yang sudah di input, tombol edit untuk mengedit data atau mengubah data, tombol hapus untuk menghapus data yang sudah terdapat pada record data detail pengecekan barang dan tombol tutup untuk keluar dari form data pengecekan barang.

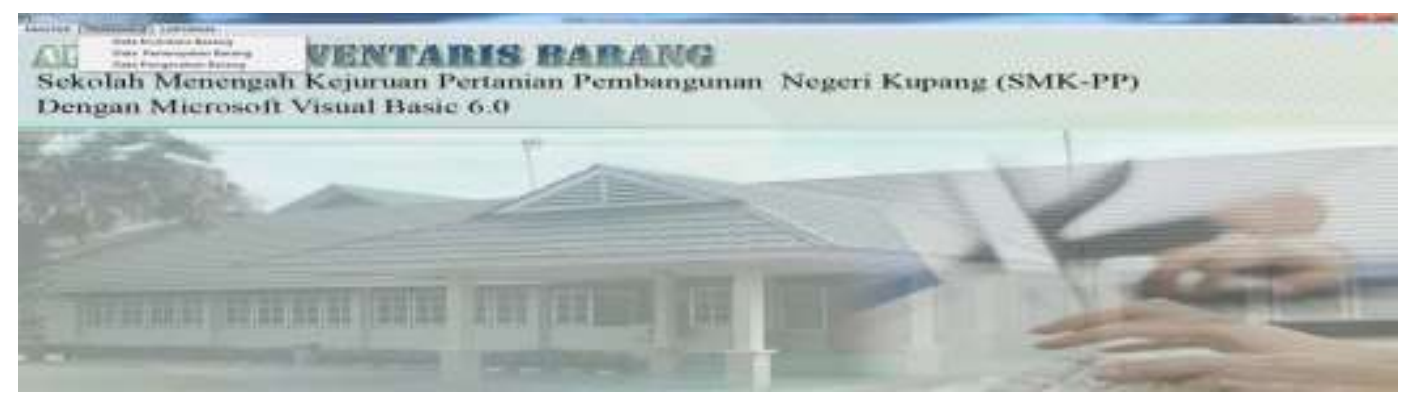

\section{Gambar 9. Sub Menu Transaksi}

\section{b. Sub Menu Laporan}

Di dalam menu laporan terdapat beberapa sub bagian lagi yang digunakan untuk mengolah data laporan inventaris barang terlihat pada gambar 10

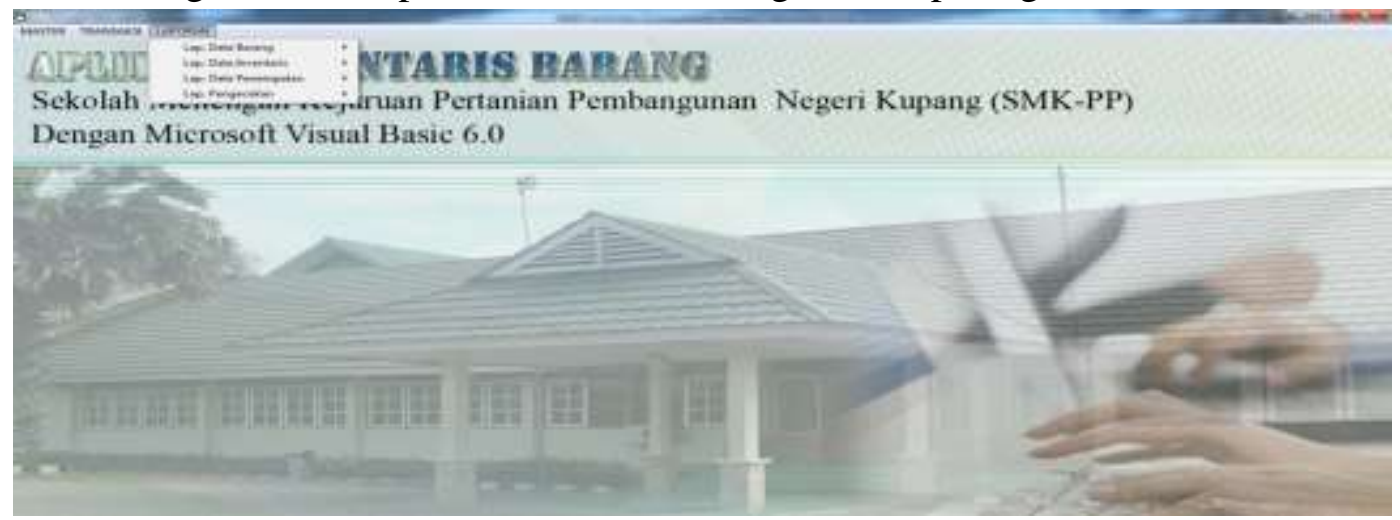

\section{Gambar 10. Sub Menu Laporan}

\section{KESIMPULAN}

Proses perancangan dan implementasi selesai dilakukan, maka penulis dapat mengambil kesimpulan antara lain:

1. Penulis telah berhasil membuat aplikasi yang berguna untuk membantu dalam pendataan barang inventaris pada Sekolah Menengah Kejuruan Pertanian Pembangunan (SMK-PP) Negeri Kupang.

2. Mempermudah petugas dalam memasukan data barang.

3. Dari penelitian yang dilakukan penulis, maka dapat mengetahui sistem yang sedang berjalan pada instansi Sekolah Menengah Kejuruan Pertanian Pembangunan (SMK-PP) Negeri Kupang, khususnya pada bagian tata usaha.

4. Program pendataan ini dapat menghasilkan laporan-laporan yang dibutuhkan pada bagian pendataan barang inventaris. 
5. Dengan laporan ini juga dapat membantu mencetak pelaporan inventaris dengan lebih cepat dan akurat secara otomatis.

\section{SARAN}

Dari kesimpulan diatas, maka ada beberapa saran yang ingin sisampaikan oleh penilis:

1. Sekolah Menengah Kejuruan Pertanian Pembangunan (SMK-PP) Negeri Kupang sebaiknya menambah 1 unit komputer khususnya untuk administrator. Sehingga aplikasi yang penulis buat ini bisa dipakai dan tidak mengganggu kegiatan pada komputer lain.

2. Memperbaiki cara pengelolaan barang inventaris di satuan kerja (tata usaha) yang semula yang dikelola dalam Excel di ubah menjadi pengelolaan dalam sebuah aplikasi

3. Untuk mendapatkan data dan sistem informasi yang lengkap dan tepat serta cepat hendaknya tidak lagi menggunakan sistem yang lama tetapi dialihkan kedalam aplikasi atau sistem yang baru melalui program Microsoft Visual Basic 6.0

\section{UCAPAN TERIMA KASIH}

Penulis mengucapkan terimakasih kepada STMIK Widya Dharma Pontianak dan yayasan yang telah memberi dukungan financial terhadap penelitian ini.

\section{DAFTAR PUSTAKA}

[1] Elisabeth thedens, 2009, program bantu pendataan barang inventaris kantor pada dinas tenaga kerja dan transmigrasi Provinsi Nusa Tenggara Timur, STIKOM UYELINDO Kupang, NTT.

[2] Indra Haryanto Ali, 2011, Aplikasi rencana kerja tahunan puskesmas pada dinas kesehatan kota kupang berbasis client server, STIKOM UYELINDO Kupang, NTT

[3] Sugiono, 2003, cetakan ke lima, Statistika Untuk Penelitian, Bandung, Alfabetta

[4] Kurt Lewin, 1990, Action Research Minority Problems, 3rd ed. Victoria : Deaklin University.

[5] Arikunto Suharsimi. 2006. Prosedur Penelitian Suatu Pendekatan Praktik.: penerbit Rineka Cipta, Jakarta

[6] Hadari Nawawi dan Martini Nawawi, 1995, Instrumen Penelitian Bidang Sosial, Gadjah Mada University Press, Yogyakarta,

[7] Moleong, L. J, 2004, Metodologi Penelitian Kualitatif, Bandung : PT Remaja Rosdakarya

[8] Moleong, Lexy J, 2007, Metodologi Penelitian Kualitatif, Penerbit PT Remaja Rosdakarya Offset, Bandung

[9] Punch, K.F. 1998. Introduction to Social Research, Quantitative and Qualitative Approach. British: SAGE Publications. 